\title{
Sphingomonas aquatilis sp. nov., Sphingomonas koreensis sp. nov. and Sphingomonas taejonensis sp. nov., yellow-pigmented bacteria isolated from natural mineral water
}

\footnotetext{
${ }^{1}$ Korea Research Institute of Bioscience and Biotechnology, PO Box 115 , Yusong, Taejon 305-600, Korea

2 Institute for Fermentation, Osaka, Yodogawa-ku, Osaka 532, Japan

3 Department of Biotechnology, Yonsei University, Seoul 120-749, Korea
}

\author{
Jung-Sook Lee, ${ }^{1,3}$ Yong Kook Shin, ${ }^{1}$ Jung-Hoon Yoon, ${ }^{1}$ Mariko Takeuchi, ${ }^{2}$ \\ Yu-Ryang Pyun ${ }^{3}$ and Yong-Ha Park ${ }^{1}$
}

\begin{abstract}
Author for correspondence: Yong-Ha Park. Tel: +82 42860 4620. Fax: +82 428621315 e-mail: yhpark@mail.kribb.re.kr
\end{abstract}

\begin{abstract}
The taxonomic status of four strains from several mineral water sources in Taejon, Korea, was examined. The DNA base compositions of these strains ranged from 62 to $66 \mathrm{~mol} \%$. All of the strains contained sphingolipids and ubiquinone $\mathbf{1 0}$ as the main respiratory quinone. The cellular fatty acids of these strains included octadecenoic acid, hexadecanoic acid and 2-hydroxymyristic acid, without 3-hydroxy fatty acids. On the basis of morphological, physiological and chemotaxonomic characteristics, together with 165 rDNA sequence comparison and DNA-DNA reassociation data, three new species of the genus Sphingomonas are proposed for the strains isolated from natural mineral water: Sphingomonas aquatilis sp. nov. for strain JSS7 ${ }^{\top}$ ( = KCTC $2881^{\top}$ $=\mathrm{KCCM} \mathrm{41067'),} \mathrm{Sphingomonas} \mathrm{koreensis} \mathrm{sp.} \mathrm{nov.} \mathrm{for} \mathrm{strains} \mathrm{JSS26}^{\top}(=$ KCTC

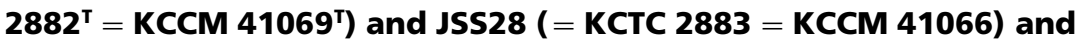
Sphingomonas taejonensis sp. nov. for strain JSS54 $\left(=\mathrm{KCTC}^{\top} 2884^{\top}=\mathrm{KCCM}^{\top}\right.$ 41068').
\end{abstract}

Keywords: Sphingomonas, mineral water, taxonomy

\section{INTRODUCTION}

As industry develops, environmental pollution becomes an increasing problem. Recently, water pollution has become more serious and concern has also increased about the quality of natural mineral water. In most natural mineral waters, bacterial cells are assumed to exist under starvation conditions and growth will be limited primarily by low concentrations of suitable carbon and energy sources. Therefore, it has been presumed that the conditions in most mineral water used for drinking make it difficult for bacteria to grow (Manaia et al., 1990; Quevedo-Sarmiento et al., 1986; Taylor et al., 1983). However, yellow-pigmented bacterial colonies were frequently encountered on nutrient agar isolation plates when we investigated the

Abbreviation: Q-10, ubiquinone 10.

The GenBank accession numbers for the 16S rDNA sequences of strains JSS7 $^{\top}, \mathrm{JSS}^{\top} 6^{\top}, \mathrm{JSS} 28$ and JSS54 ${ }^{\top}$ are respectively AF131295, AF131296, AF031240 and AF131297. microbial ecosystems present in natural mineral water samples. The isolation and characterization of some bacteria from natural mineral waters has been reported (Manaia et al., 1990; Quevedo-Sarmiento et al., 1986; Taylor et al., 1983), but there has been little study regarding yellow-pigmented bacteria. Therefore, we isolated and identified yellow-pigmented bacteria from natural mineral water from several places in the city of Taejon, Korea. The isolates were yellow-pigmented, Gram-negative, aerobic and motile rods with single polar flagella and contained ubiquinone $10(\mathrm{Q}-10)$ and 2-hydroxy fatty acids without 3-hydroxy fatty acids. On the basis of these characteristics, we judged that the isolates belonged to the genus Sphingomonas.

The genus Sphingomonas was first proposed by Yabuuchi et al. (1990) and later emended by Takeuchi et al. (1993). Members of the genus Sphingomonas are yellow-pigmented, Gram-negative, aerobic, nonspore-forming, non-fermentative, motile or non-motile rods and are characterized chemotaxonomically by the presence of Q-10, 2-hydroxy fatty acids and 
sphingolipid and the absence of 3-hydroxy fatty acids (Balkwill et al., 1997; Kawahara et al., 1994; Nohynek et al., 1995; Takeuchi et al., 1993, 1995; Wilkes et al., 1996; Yabuuchi et al., 1979, 1990).

In this study, we report the morphological, biochemical and phylogenetic characteristics of yellow-pigmented bacteria isolated from natural mineral water. We also propose that four of the isolates be assigned to three new species of Sphingomonas, Sphingomonas aquatilis sp. nov., Sphingomonas koreensis sp. nov. and Sphingomonas taejonensis sp. nov.

\section{METHODS}

Micro-organisms and cultures. The bacterial strains used in this study were isolated from natural mineral water in Taejon, Korea. Samples $(250 \mathrm{ml})$ were collected in sterile bottles and filtered through a $0.45 \mu \mathrm{m}$ Millipore filter. Filters were placed face-up on nutrient agar (Difco) plates and incubated at $30{ }^{\circ} \mathrm{C}$ for $7 \mathrm{~d}$. Yellow-pigmented colonies were observed and isolated. The type strains of Sphingomonas paucimobilis, KCTC $2885^{\mathrm{T}} \quad\left(=\mathrm{IFO} \quad 13935^{\mathrm{T}}=\mathrm{ATCC}\right.$ $29837^{\mathrm{T}}$ ), and Sphingomonas yanoikuyae, KCTC $2818^{\mathrm{T}}(=$ IFO $15102^{\mathrm{T}}=$ ATCC $51230^{\mathrm{T}}$ ), were obtained from the Korean Collection for Type Cultures, Taejon, Korea, as reference strains. The strains used are listed in Table 1. All strains were cultured routinely on nutrient agar and on trypticase soy agar for fatty acid analysis. The cultures were incubated at $30^{\circ} \mathrm{C}$ for $2 \mathrm{~d}$.

Determination of phenotypic characteristics. Cell morphology was examined by light microscopy. Motility was determined with an optical microscope using the hanging drop technique (Skerman, 1967). The flagellum type was determined by transmission electron microscopy using cells from the exponential growth phase. Cells were negatively stained with $1 \%(\mathrm{w} / \mathrm{v})$ phosphotungstic acid and, after airdrying, the grids were examined by using a model CM-20 transmission electron microscope (Philips). The API 20NE and API ID32GN systems (bioMérieux) were used for physiological and biochemical characteristics. API ID32GN galleries were used to determine the carbohydrate assimilation pattern of the organisms. All API tests were performed in accordance with the manufacturer's directions. Fermentative acid production and oxidative acid production from carbohydrates were tested by growth in OF basal medium (Difco) supplemented with $0 \cdot 5-1 \%$ carbohydrate [soft-agar stabs with (fermentative) and without (oxidative) sterile mineral oil overlay]. The OF medium tubes were incubated at $30^{\circ} \mathrm{C}$ for $10 \mathrm{~d}$.

Cellular fatty acid analysis. Bacterial cultures were harvested from trypticase soy agar for total cellular fatty acid analysis. Fatty acids were extracted by following the Microbial Identification System instructions, as described previously (Lee et al., 1996; Yang et al., 1993).

Sphingolipid analysis. The long-chain bases of the cellular sphingolipids were analysed as described by Yano et al. (1982).

DNA base composition. DNA was extracted and purified by a modification of the method of Marmur (1961). The $G+C$ content of DNA was determined by the reverse-phase HPLC method described by Tamaoka \& Komagata (1984).

DNA-DNA hybridization. DNA-DNA hybridization was carried out by fluorometric hybridization in microdilution wells using biotinylated DNA (Ezaki et al., 1989).

Identification of isoprenoid quinone. Isoprenoid quinones were extracted with chloroform/methanol $(2: 1, \mathrm{v} / \mathrm{v})$ and purified by TLC on Merck Kieselgel $60 \mathrm{~F}_{254}$ plates $(20 \times 20 \mathrm{~cm}, 0.5 \mathrm{~mm}$ thick) using a mixture of petroleum ether and diethyl ether $(9: 1, \mathrm{v} / \mathrm{v})$ as the solvent and then analysed by HPLC as described by Shin et al. (1996).

16S rDNA sequence analysis. 16S rDNA sequencing from the four strains was described by Yoon et al. (1998). Two primers described by Stackebrandt \& Liesack (1993), 9F (5'GAGTTTGATCCTGGCTCAG-3'; positions 9-27 according to Escherichia coli $16 \mathrm{~S}$ rRNA numbering) and 1542R (5'AGAAAGGAGGTGATCCAGCC-3'; positions 15421525), were used for amplification of the $16 \mathrm{~S}$ rRNA gene. The $5^{\prime}$ ends of the two primers were phosphorylated using T4 polynucleotide kinase (New England Biolabs) according to the instructions of the Strandase ssDNA preparation kit (Novagen). The 16S rRNA gene was amplified as described by Yoon et al. (1997) in separate reactions containing phosphorylated 9F plus non-phosphorylated 1542R and phosphorylated $1542 \mathrm{R}$ plus non-phosphorylated $9 \mathrm{~F}$ primers. PCR products were precipitated with $1 \mu 11 \%$ $(\mathrm{w} / \mathrm{v})$ glycogen, $9 \mu \mathrm{l} 3 \mathrm{M}$ sodium acetate $(\mathrm{pH} 5 \cdot 2)$ and $70 \mu \mathrm{l}$ 2-propanol and resuspended in $10 \mu \mathrm{l}$ distilled water. Strands containing phosphorylated primer from PCR products were selectively digested using $\lambda$ exonuclease according to the Strandase ssDNA preparation kit instructions. The ssDNA templates produced were used directly for the sequencing

Table 1. Sphingomonas strains included in this study

Culture collections are abbreviated as: KCTC, Korean Collection for Type Cultures, Taejon, Korea; IFO, Institute for Fermentation, Osaka, Japan; KCCM, Korean Culture Center of Microorganisms, Seoul, Korea. All taxa listed are positive for sphingolipid and have Q-10 as the major isoprenoid quinone.

\begin{tabular}{|c|c|c|c|}
\hline Strain & Other designation & Source & DNA G $+C$ content $(\mathrm{mol} \%)$ \\
\hline JSS7 $\left(=\right.$ KCTC $\left.2881^{\mathrm{T}}\right)$ & $\mathrm{KCCM} 41067^{\mathrm{T}}$ & Natural mineral water, Korea & 63 \\
\hline JSS26 ( = KCTC 2882 $)$ & KCCM $41069^{\mathrm{T}}$ & Natural mineral water, Korea & 66 \\
\hline JSS28 (= KCTC 2883) & KCCM 41066 & Natural mineral water, Korea & 66 \\
\hline JSS54 (= KCTC 2884 $\left.{ }^{\mathrm{T}}\right)$ & $\mathrm{KCCM} 41068^{\mathrm{T}}$ & Natural mineral water, Korea & 63 \\
\hline Sphingomonas paucimobilis KCTC $2885^{\mathrm{T}}$ & IFO $13935^{\mathrm{T}}$ & - & 64 \\
\hline Sphingomonas yanoikuyae KCTC $2818^{\mathrm{T}}$ & IFO $15102^{\mathrm{T}}$ & - & 62 \\
\hline
\end{tabular}


reaction. Sequencing was performed as described by Kim et al. (1995) using $\left[{ }^{35} \mathrm{~S}\right] \mathrm{dATP} \alpha \mathrm{S}$ and a DNA sequencing kit (USB) according to the manufacturer's instructions.

Phylogenetic analysis. The $16 \mathrm{~S}$ rDNA sequences of strains $\mathrm{JSS}^{\mathrm{T}}, \mathrm{JSS} 26^{\mathrm{T}}$, JSS28 and $\mathrm{JSS} 54^{\mathrm{T}}$ were aligned with $16 \mathrm{~S}$ rRNA and rDNA sequences of representatives of the genus Sphingomonas and related taxa by using the CLUSTAL W software (Thompson et al., 1994). Gaps at the 5' and 3' ends of the alignment were omitted from further analysis. Evolutionary distance matrices were calculated by using the algorithm of Jukes \& Cantor (1969) with the DNADIST program within the PHYLIP package (Felsenstein, 1993). A phylogenetic tree was constructed by using the neighbourjoining method (Saitou \& Nei, 1987) as implemented within the NEIGHBOR program of the same package. The stability of relationships was assessed by bootstrap analysis of 1000 data sets with the programs SEQBOOT, DNADIST, NEIGHBOR and CONSENSE of the PHYLIP package.

\section{RESULTS AND DISCUSSION}

\section{Morphological and physiological characteristics}

All of the strains were Gram-negative, motile rods with single polar flagella (Fig. 1). All of the isolates gave positive results for aesculin hydrolysis, $\beta$ galactosidase, oxidase, catalase and assimilation of glucose and negative results for nitrate reduction, indole production, glucose acidification, arginine hy-

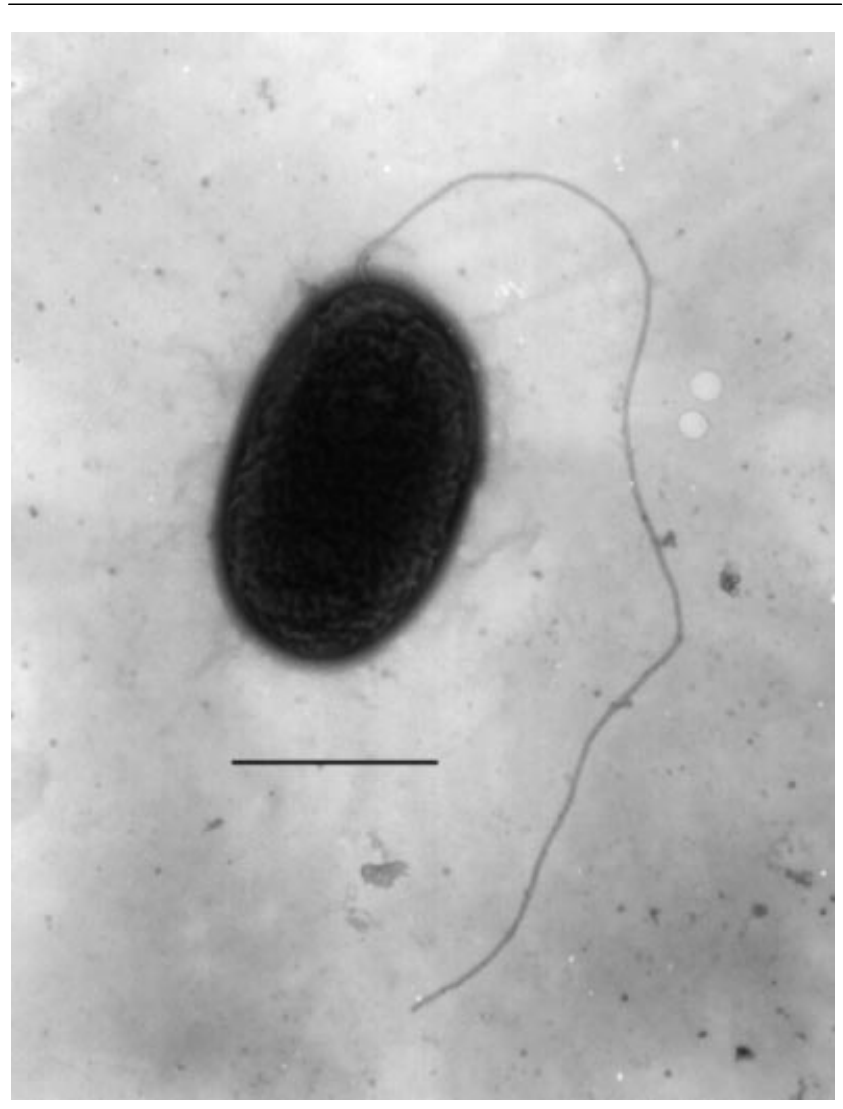

Fig. 1. Transmission electron micrograph of strain JSS54 ${ }^{\top}$. Bar, $1 \mu \mathrm{m}$. drolysis, urease, gelatin hydrolysis and assimilation of 2-ketogluconate, 5-ketogluconate, adipate, D-ribose, D-sorbitol, glycogen and phenylacetate. Table 2 shows differential characteristics for 20 Sphingomonas species; isolates $\mathrm{JSS} 7^{\mathrm{T}}$, JSS26 ${ }^{\mathrm{T}}$, JSS28 and $\mathrm{JSS} 54^{\mathrm{T}}$ can be differentiated from other Sphingomonas species on the basis of the results of several tests included in Table 2.

\section{Chemotaxonomic characteristics}

All of the isolates contained Q-10 and sphingolipid and the DNA base composition $(\mathrm{G}+\mathrm{C}$ content $)$ ranged from 63 to $66 \mathrm{~mol} \%$. The major whole-cell fatty acids in the test strains were octadecenoic acid (18:1), hexadecanoic acid (16:0) and 2-hydroxymyristic acid (14:0 2-OH), which was the predominant hydroxy fatty acid (Table 3). Three of the isolates, $\mathrm{JSS}^{2}{ }^{\mathrm{T}}$, JSS28 and JSS54 ${ }^{\mathrm{T}}$, contained 2-hydroxypentadecanoic acid $(15: 0$ 2-OH) and 2-hydroxyhexadecanoic acid $(16: 02-\mathrm{OH})$ in addition to 2hydroxymyristic acid. None of the strains contained 3-hydroxy fatty acids.

\section{DNA-DNA reassociation analysis}

As shown in Table 4, DNA-DNA reassociation values between the four isolates and all of the other strains tested were less than $26 \%$. Isolates JSS26 ${ }^{\mathrm{T}}$ and JSS28 exhibited high levels of homology (90-102\%) with each other, but lower levels of homology with JSS7 ${ }^{\mathrm{T}}$ (16-18\%) and JSS54 ${ }^{\mathrm{T}}(11-15 \%)$. The DNA-DNA reassociation values between $\mathrm{JSS} 7^{\mathrm{T}}$ and the other three isolates and between $\mathrm{JSS} 54^{\mathrm{T}}$ and the other three isolates were less than $18 \%$.

\section{Phylogenetic analysis}

Nearly complete 16S rDNA sequences (positions 28-1524, E. coli numbering) were determined for $\mathrm{JSS}^{\mathrm{T}}{ }^{2}, \mathrm{JSS} 26^{\mathrm{T}}$, JSS 28 and $\mathrm{JSS} 54^{\mathrm{T}}$. The primary structures of the $16 \mathrm{~S}$ rDNA sequences of these strains were compared with each other and with those of closely related reference strains. A phylogenetic tree based on $K_{\text {nuc }}$ values, shown in Fig. 2, indicates that these strains belong to the genus Sphingomonas.

The levels of $16 \mathrm{~S}$ rDNA sequence similarity confirmed that isolates $\mathrm{JSS}^{\mathrm{T}}, \mathrm{JSS} 26^{\mathrm{T}}$, JSS28 and $\mathrm{JSS}^{2} 4^{\mathrm{T}}$ all belong to the genus Sphingomonas. Three of the isolates (JSS7 ${ }^{\mathrm{T}}$, JSS2 $^{\mathrm{T}}{ }^{\mathrm{T}}$ and JSS28) were most closely related to Sphingomonas asaccharolytica, Sphingomonas pruni and Sphingomonas mali, and formed a distinct cluster with these strains (Fig. 2). Two of these strains (JSS26 ${ }^{\mathrm{T}}$ and JSS28) had identical 16S rDNA gene sequences, implying that they may be members of the same species. The levels of sequence similarity between these strains and S. asaccharolytica, S. pruni and $S$. mali were somewhat lower $(97 \cdot 8-98 \cdot 1 \%)$. Isolate $\mathrm{JSS} 7^{\mathrm{T}}$ was phylogenetically most closely related to strains JSS $26^{\mathrm{T}}$ and JSS28, but was always separated 
Table 2. Morphological and physiological characteristics of Sphingomonas species

Taxa are identified as: 1, S. chlorophenolica; 2, S. yanoikuyae; 3, S. suberifaciens; 4, S. macrogoltabidus; 5, S. adhaesiva; 6, S. terrae; 7, S. capsulata; 8, S. subarctica; 9, S. rosa; 10, S. natatoria; 11, S. mali; 12, S. pruni; 13, S. asaccharolytica; 14, S. parapaucimobilis; 15, S. sanguinis; 16, S. paucimobilis; 17, S. trueperi; 18, S. aquatilis JSS7 ${ }^{\mathrm{T}} ; 19$, S. koreensis JSS26 ${ }^{\mathrm{T}} ; 20$, S. taejonensis $\mathrm{JSS}_{5}{ }^{\mathrm{T}}$. Strain JSS28 gave identical results to JSS26 ${ }^{\mathrm{T}}$. All taxa are positive for motility and aesculin hydrolysis and negative for Gram staining. Cells are rod-shaped. Characteristics are scored as: +, positive; -, negative; w, weak; NT, not tested. Data in columns 1,3-15 and 17 were taken from Kämpfer et al. (1997), Takeuchi et al. (1993, 1995) and Yabuuchi et al. $(1990,1999)$.

\begin{tabular}{|c|c|c|c|c|c|c|c|c|c|c|c|c|c|c|c|c|c|c|c|c|}
\hline Characteristic & 1 & 2 & 3 & 4 & 5 & 6 & 7 & 8 & 9 & 10 & 11 & 12 & 13 & 14 & 15 & 16 & 17 & 18 & 19 & 20 \\
\hline Colony colour* & $\mathrm{Y}$ & $\mathrm{Y}$ & w & $\mathrm{Y}$ & $\mathrm{Y}$ & $\mathrm{Y}$ & $\mathrm{Y}$ & $\mathrm{Y}$ & $\mathrm{Y}$ & o & $\mathrm{Y}$ & $\mathrm{Y}$ & $\mathrm{Y}$ & $\mathrm{Y}$ & $\mathrm{Y}$ & $\mathrm{Y}$ & $\mathrm{Y}$ & $\mathrm{Y}$ & $\mathrm{Y}$ & PY \\
\hline Reduction of nitrate & NT & - & - & - & - & - & - & NT & w & - & - & - & - & + & - & - & NT & - & - & - \\
\hline Hydrolysis of gelatin & NT & - & - & - & - & - & - & NT & - & - & - & - & - & - & - & - & + & - & - & - \\
\hline \multicolumn{21}{|l|}{ Assimilation of: } \\
\hline Adipate & - & - & - & - & - & w & - & - & - & + & w & - & - & - & - & - & - & - & - & - \\
\hline Caprate & - & + & - & - & - & - & - & - & - & - & - & - & - & - & - & - & - & + & - & + \\
\hline Citrate & - & + & - & - & - & - & - & + & - & - & - & - & - & + & - & - & - & - & - & - \\
\hline D-Melibiose & - & + & NT & - & + & - & - & NT & + & NT & + & + & + & + & + & + & + & - & + & - \\
\hline D-Sucrose & - & + & NT & - & + & - & + & NT & + & NT & + & + & $\mathrm{w}$ & + & + & + & + & + & + & - \\
\hline Gluconate & - & + & NT & - & - & - & + & - & + & - & + & + & - & + & - & - & - & - & - & - \\
\hline L-Arabinose & - & + & - & + & - & - & + & + & + & + & + & + & + & + & + & + & + & + & - & - \\
\hline Malate & - & + & - & - & + & + & + & + & + & - & - & - & - & + & + & + & + & - & + & + \\
\hline Maltose & - & + & - & + & + & - & + & + & + & + & + & + & + & + & + & + & + & + & + & - \\
\hline Mannose & - & - & - & - & + & - & + & - & + & - & + & + & + & + & + & + & + & - & - & - \\
\hline $\mathrm{N}$-Acetylglucosamine & - & + & - & - & + & - & + & + & w & - & + & + & + & + & + & + & + & + & + & - \\
\hline Rhamnose & - & + & NT & - & - & - & + & + & + & NT & + & + & + & $\mathrm{w}$ & - & - & - & + & + & - \\
\hline Salicin & - & + & NT & - & + & - & - & NT & + & NT & + & + & w & + & + & + & + & w & + & - \\
\hline \multicolumn{21}{|c|}{ Oxidative acid production (OF medium) from: } \\
\hline Glycerol & NT & + & NT & - & + & - & + & NT & - & NT & - & - & - & - & + & - & - & - & - & - \\
\hline Rhamnose & - & + & NT & - & + & - & + & $\mathrm{NT}$ & + & NT & + & - & - & + & + & - & - & + & w & - \\
\hline
\end{tabular}

*o, Orange; PY, pale yellow; y, yellow; w, white.

Table 3. Cellular fatty acid profiles of isolates and reference strains

Summed features represent groups of two or three fatty acids that could not be separated by GLC with the MIDI system: summed feature 4 contained one or more of 15:0 iso $2-\mathrm{OH}$ and/or $16: 1 \omega 7 t$; summed feature 7 contained one or more of 18: $1 \omega 7 c, 18: 1 \omega 9 t$ and/or $18: 1 \omega 12 t$. ND, Not detected.

\begin{tabular}{|c|c|c|c|c|c|c|}
\hline Fatty acid & S. paucimobilis KCTC $2885^{\mathrm{T}}$ & S. yanoikuyae КСТC $2818^{\mathrm{T}}$ & $\mathbf{J S S}^{\mathrm{T}}$ & $\mathbf{J S S 2 6}^{\mathrm{T}}$ & JSS28 & $\mathrm{JSS54}^{\mathrm{T}}$ \\
\hline \multicolumn{7}{|c|}{ Saturated fatty acids: } \\
\hline $14: 0$ & $1 \cdot 52$ & $0 \cdot 52$ & $0 \cdot 70$ & $1 \cdot 85$ & $0 \cdot 95$ & ND \\
\hline $15: 0$ & $0 \cdot 52$ & ND & ND & $0 \cdot 23$ & $0 \cdot 26$ & $2 \cdot 32$ \\
\hline $16: 0$ & $9 \cdot 26$ & $15 \cdot 40$ & $20 \cdot 58$ & $12 \cdot 98$ & $8 \cdot 82$ & $22 \cdot 96$ \\
\hline $17: 0$ & $0 \cdot 29$ & ND & ND & ND & ND & $1 \cdot 61$ \\
\hline $18: 0$ & $0 \cdot 72$ & ND & $1 \cdot 04$ & $0 \cdot 55$ & $0 \cdot 40$ & ND \\
\hline \multicolumn{7}{|c|}{ Unsaturated fatty acids: } \\
\hline $16: 1 \omega 5 c$ & $0 \cdot 71$ & $2 \cdot 90$ & $0 \cdot 81$ & $1 \cdot 28$ & $1 \cdot 56$ & $1 \cdot 56$ \\
\hline $17: 1 \omega 8 c$ & $0 \cdot 50$ & ND & ND & $0 \cdot 35$ & ND & $1 \cdot 80$ \\
\hline $17: 1 \omega 7 c$ & ND & $0 \cdot 83$ & ND & ND & ND & ND \\
\hline $17: 1 \omega 6 c$ & $1 \cdot 76$ & $1 \cdot 59$ & ND & $1 \cdot 47$ & $1 \cdot 57$ & $11 \cdot 88$ \\
\hline $18: 1 \omega 5 c$ & $3 \cdot 42$ & $3 \cdot 12$ & $1 \cdot 51$ & 1.76 & $1 \cdot 81$ & ND \\
\hline \multicolumn{7}{|l|}{ Hydroxy fatty acids: } \\
\hline $14: 02-\mathrm{OH}$ & $6 \cdot 36$ & $7 \cdot 44$ & $10 \cdot 86$ & $9 \cdot 42$ & $10 \cdot 08$ & $4 \cdot 35$ \\
\hline $15: 02-\mathrm{OH}$ & $0 \cdot 16$ & ND & ND & $0 \cdot 29$ & $0 \cdot 34$ & $2 \cdot 31$ \\
\hline $16: 02-\mathrm{OH}$ & ND & $0 \cdot 84$ & ND & 0.79 & $0 \cdot 82$ & $1 \cdot 47$ \\
\hline Summed feature 4 & $2 \cdot 67$ & $15 \cdot 75$ & $4 \cdot 61$ & $2 \cdot 06$ & $2 \cdot 06$ & $21 \cdot 49$ \\
\hline Summed feature 7 & $72 \cdot 11$ & $51 \cdot 60$ & $59 \cdot 89$ & 66.97 & $71 \cdot 33$ & $28 \cdot 27$ \\
\hline
\end{tabular}

from those strains on a distinct branch of the tree (Fig. 2 ). The level of sequence similarity between it and $\mathrm{JSS}^{2} 6^{\mathrm{T}}$ and $\mathrm{JSS} 28$ was $97 \cdot 0 \%$. Isolate $\mathrm{JSS}^{\mathrm{T}}{ }^{\mathrm{T}}$ was most closely related to Sphingomonas macrogoltabidus. However, a comparison of levels of sequence similarity between it and $\mathrm{JSS}_{54}{ }^{\mathrm{T}}(97 \cdot 7 \%)$ revealed that isolate 
Table 4. DNA-DNA reassociation values for various Sphingomonas strains

\begin{tabular}{|c|c|c|c|c|}
\hline \multirow[t]{2}{*}{ Strain } & \multicolumn{4}{|c|}{ Reassociation (\%) with labelled DNA from: } \\
\hline & $\mathrm{JSS7}^{\mathrm{T}}$ & $\mathbf{J S S 2 6}^{\mathrm{T}}$ & JSS28 & JSS54 $^{\mathrm{T}}$ \\
\hline $\mathrm{JSS}^{\mathrm{T}}$ & 100 & 18 & 16 & 11 \\
\hline $\mathrm{JSS} 26^{\mathrm{T}}$ & 16 & 100 & 90 & 15 \\
\hline JSS28 & 14 & 102 & 100 & 16 \\
\hline JSS54 ${ }^{\mathrm{T}}$ & 18 & 15 & 11 & 100 \\
\hline S. adhaesiva KCTC $2812^{\mathrm{T}}$ & 11 & 17 & 16 & 11 \\
\hline S. aromaticivorans IFO $16084^{\mathrm{T}}$ & 10 & 11 & 9 & 16 \\
\hline S. asaccharolytica KCTC $2825^{\mathrm{T}}$ & 18 & 5 & 14 & 16 \\
\hline S. capsulata IFO $12533^{\mathrm{T}}$ & 9 & 16 & 20 & 7 \\
\hline S. macrogoltabidus KCTC $2813^{\mathrm{T}}$ & 7 & 6 & 16 & 19 \\
\hline S. mali KCTC $2826^{\mathrm{T}}$ & 14 & 7 & 18 & 14 \\
\hline S. parapaucimobilis KCTC $2815^{\mathrm{T}}$ & 14 & 12 & 22 & 9 \\
\hline S. paucimobilis KCTC $2885^{\mathrm{T}}$ & 18 & 12 & 27 & 13 \\
\hline S. pruni KCTC $2824^{\mathrm{T}}$ & 16 & 9 & 14 & 10 \\
\hline S. rosa KCTC $2821^{\mathrm{T}}$ & 10 & 11 & 11 & 9 \\
\hline S. sanguinis $\mathrm{IFO} 13937^{\mathrm{T}}$ & 18 & 10 & 16 & 5 \\
\hline S. stygia IFO $16085^{\mathrm{T}}$ & 16 & 6 & 9 & 18 \\
\hline S. subarctica IFO $16058^{\mathrm{T}}$ & 8 & 9 & 11 & 17 \\
\hline S. subterranea IFO $16086^{\mathrm{T}}$ & 13 & 10 & 16 & 12 \\
\hline S. terrae $\mathrm{KCTC} 2814^{\mathrm{T}}$ & 13 & 7 & 11 & 26 \\
\hline S. yanoikuyae KCTC $2818^{\mathrm{T}}$ & 21 & 14 & 8 & 13 \\
\hline S. natatoria IFO $15649^{\mathrm{T}}$ & 12 & 10 & 11 & 13 \\
\hline S. suberifaciens $\mathrm{KCTC} 2841^{\mathrm{T}}$ & 20 & 10 & 9 & 8 \\
\hline Brevundimonas subvibrioides IFO $16000^{\mathrm{T}}$ & 24 & 8 & 12 & 7 \\
\hline
\end{tabular}

JSS54 ${ }^{\mathrm{T}}$ represents a distinct species of the genus Sphingomonas.

As mentioned above, the chemotaxonomic and physiological characteristics and phylogenetic data showed that all of the isolated strains that we studied are members of the genus Sphingomonas.

\section{Conclusions}

Members of the genus Sphingomonas contain sphingoglycolipid with the long-chain base dihydrosphingosin and do not contain lipopolysaccharide. They contain Q-10 and 2-hydroxymyristate and do not contain 3hydroxy fatty acids. The DNA $\mathrm{G}+\mathrm{C}$ content of Sphingomonas species is $62-67 \mathrm{~mol} \%$. The strains isolated from natural mineral water that we studied here have these characteristics.

Isolate JSS54 $4^{\mathrm{T}}$ has pale yellow colonies and gave negative results in assimilation of carbon sources with the exception of caprate and malate by the API 20NE and API ID32GN tests. These results show the isolate JSS54 ${ }^{\mathrm{T}}$ can be differentiated from other Sphingomonas species. Strains JSS7 ${ }^{\mathrm{T}}$, JSS26 ${ }^{\mathrm{T}}$ and JSS28 also have different physiological characteristics, as shown in Table 2.

A comparison of the 16S rDNA sequences of isolates $\mathrm{JSS}^{\mathrm{T}}{ }^{\mathrm{JSSS}} 2^{\mathrm{T}}$ and $\mathrm{JSS} 54^{\mathrm{T}}$ with sequences reported previously (Takeuchi et al., 1995; Nohynek et al., 1996) resulted in relatively high levels of similarity (97.0-98.1\%), but DNA-DNA reassociation values between these isolates and all of the other type strains tested were less than $27 \%$. These values demonstrate that the four isolates are not related to any of the previously described taxa at the species level.

On the basis of morphological, physiological and chemotaxonomic characteristics, together with DNA-DNA hybridization and 16S rDNA sequence comparison data, we propose that the isolates from natural mineral water from Korea should be assigned to three new species of the genus Sphingomonas: Sphingomonas aquatilis (for strain $\mathrm{JSS}^{\mathrm{T}}=\mathrm{KCTC}$ $2881^{\mathrm{T}}$ ), Sphingomonas koreensis (for strains JSS26 ${ }^{\mathrm{T}}=$ KCTC $2882^{\mathrm{T}}$ and JSS28 = KCTC 2883) and Sphingomonas taejonensis (for strain JSS54 ${ }^{\mathrm{T}}=\mathrm{KCTC} 2884^{\mathrm{T}}$ ).

\section{Description of Sphingomonas aquatilis sp. nov.}

Sphingomonas aquatilis (a.qua.til'is. L. f. adj. aquatilis aquatic, growing in water).

Cells are Gram-negative rods, motile with single polar flagella. Colonies are circular, entire, low-convex, smooth, opaque and yellow. Indole, urease and arginine dihydrolase are not produced. Catalase, oxidase and $\beta$-galactosidase are positive. Gelatin is not liquified and glucose is not fermented. Reduction of nitrate and 


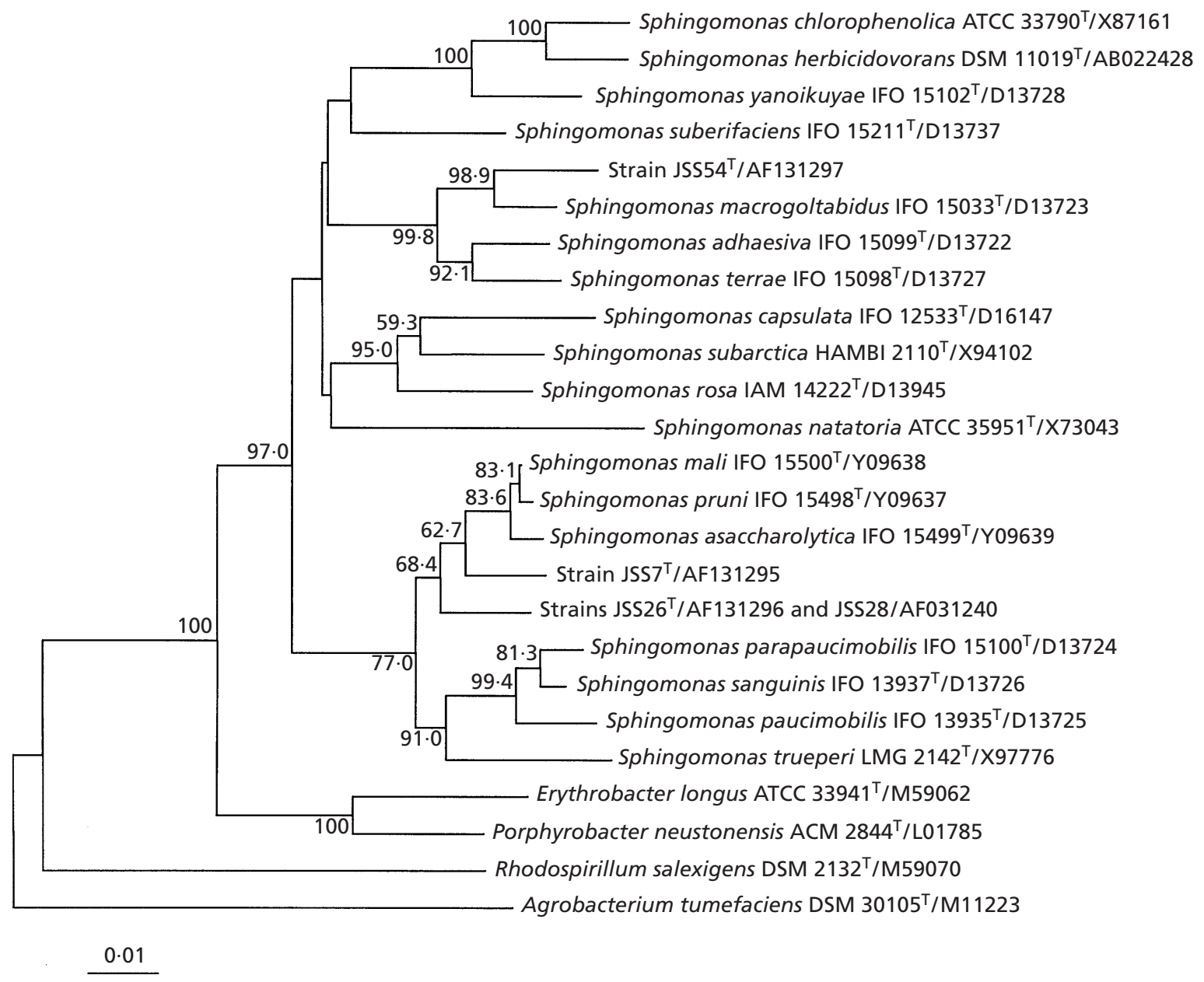

Fig. 2. Phylogenetic tree indicating the position of strains $J S S 7^{\top}, J S S 26^{\top}$, JSS28 and JSS54 ${ }^{\top}$ within the radiation of members of the genus Sphingomonas and related taxa. Sequence accession numbers are given for each strain. Bootstrap values are indicated. Bar, 0.01 accumulated change per nucleotide.

hydrolysis of aesculin are negative. Caprate, D-sucrose, glucose, L-arabinose, maltose, $N$-acetylglucosamine, rhamnose and salicin are assimilated ; 2-ketogluconate, 5-ketogluconate, adipate, citrate, D-melibiose, Dribose, D-sorbitol, gluconate, glycogen, malate, mannose and phenylacetate are not assimilated. Acid is produced oxidatively from glucose and rhamnose but not from glycerol. The $\mathrm{G}+\mathrm{C}$ content of the DNA is $63 \mathrm{~mol} \%$. The major isoprenoid quinone is ubiquinone Q-10. The major non-polar fatty acids are $18: 1 \omega 7 c$ and 16:0 and the major 2-hydroxy fatty acid is 14:0 2-OH. Sphingolipid is present.

The type strain is $\mathrm{JSS}^{\mathrm{T}}$ (= KCTC $2881^{\mathrm{T}}$, KCCM $41067^{\mathrm{T}}$ ), which was isolated from natural mineral water of Taejon City, Korea.

\section{Description of Sphingomonas koreensis sp. nov.}

Sphingomonas koreensis (ko.re.en'sis. N.L. f. adj. koreensis of Korea, from where the new organisms were isolated).
Cells are Gram-negative, motile rods with single polar flagella. Colonies are circular, entire, low-convex, smooth, opaque and yellow. Indole, urease and arginine dihydrolase are not produced. Catalase, oxidase and $\beta$-galactosidase are positive. Gelatin is not liquified and glucose is not fermented. Reduction of nitrate and hydrolysis of aesculin are negative. D-Melibiose, Dsucrose, glucose, malate, maltose, $\mathrm{N}$-acetylglucosamine, rhamnose and salicin are assimilated; 2-ketogluconate, 5-ketogluconate, adipate, caprate, citrate, D-ribose, D-sorbitol, gluconate, glycogen, L-arabinose, mannose and phenylacetate are not assimilated. Acid is weakly produced oxidatively from glucose and rhamnose, but not from glycerol. The $\mathrm{G}+\mathrm{C}$ content of the DNA is $66 \mathrm{~mol} \%$. The major isoprenoid quinone is ubiquinone Q-10. The major non-polar fatty acids are $18: 1 \omega 7 c$ and $16: 0$; the major 2-hydroxy fatty acids are 14:0 2-OH, 15:0 2-OH and16:0 2-OH. Sphingolipid is present.

Strains were isolated from natural mineral water from Taejon City, Korea. The type strain is $\mathrm{JSS}_{2} 6^{\mathrm{T}}(=$ 
$\left.\mathrm{KCTC} 2882^{\mathrm{T}}=\mathrm{KCCM} 41069^{\mathrm{T}}\right)$ and JSS28 $(=\mathrm{KCTC}$ $2883=\mathrm{KCCM} 41066)$ is a reference strain.

\section{Description of Sphingomonas taejonensis sp. nov.}

Sphingomonas taejonensis (tae.jon.en'sis. N.L. f. adj. taejonensis of Taejon, Korea, the geographical origin of the new species).

Cells are Gram-negative, motile rods with single polar flagella. Colonies are circular, entire, low-convex, smooth, opaque and pale yellow. Indole, urease and arginine dihydrolase are not produced. Catalase, oxidase and $\beta$-galactosidase are positive. Gelatin is not liquified and glucose is not fermented. Reduction of nitrate and hydrolysis of aesculin are negative. Caprate, glucose and malate are assimilated; 2-ketogluconate, 5-ketogluconate, adipate, citrate, D-melibiose, D-ribose, D-sorbitol, D-sucrose, gluconate, glycogen, L-arabinose, maltose, mannose, $\mathrm{N}$-acetylglucosamine, phenylacetate, rhamnose and salicin are not assimilated. Acid is weakly produced oxidatively from glucose, but not from rhamnose and glycerol. The $\mathrm{G}+\mathrm{C}$ content of the DNA is $63 \mathrm{~mol} \%$. The major isoprenoid quinone is ubiquinone Q-10. The major

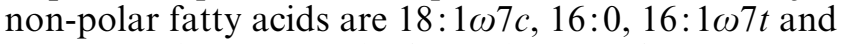
$17: 1 \omega 6 c$; the major 2-hydroxy fatty acids are 14:0 2$\mathrm{OH}, 15: 02-\mathrm{OH}$ and 16:0 2-OH. Sphingolipid is present.

The type strain, $\mathrm{JSS} 54^{\mathrm{T}}\left(=\mathrm{KCTC} 2884^{\mathrm{T}}=\mathrm{KCCM}\right.$ $41068^{\mathrm{T}}$ ), was isolated from natural mineral water from Taejon City, Korea.

\section{ACKNOWLEDGEMENTS}

We thank Professor Hans G. Trüper and Dr Akio Seino for their advice in naming the organisms and technical assistance. This study was supported financially by grant HS1331 from the Ministry of Science and Technology of the Republic of Korea.

\section{REFERENCES}

Balkwill, D. L., Drake, G. R., Reeves, R. H. \& 7 other authors. (1997). Taxonomic study of aromatic-degrading bacteria from deep-terrestrial-subsurface sediments and description of Sphingomonas aromaticivorans sp. nov., Sphingomonas subterranea sp. nov., and Sphingomonas stygia sp. nov. Int J Syst Bacteriol 47, 191-201.

Ezaki, T., Hashimoto, Y. \& Yabuuchi, E. (1989). Fluorometric deoxyribonucleic acid-deoxyribonucleic acid hybridization in microdilution wells as an alternative to membrane filter hybridization in which radioisotopes are used to determine genetic relatedness among bacterial strains. Int J Syst Bacteriol 39, 224-229.

Felsenstein, J. (1993). PHYLIP (phylogeny inference package), version 3.5c. Department of Genetics, University of Washington. Seattle: WA, USA.

Jukes, T. H. \& Cantor, C. R. (1969). Evolution of protein molecules. In Mammalian Protein Metabolism, vol. 3, pp. 21-132. Edited by H. N. Munro. New York: Academic Press.

Kämpfer, F., Denner, E. B. M., Meyer, S., Moore, E. R. B. \& Busse, H.-J. (1997). Classification of "Pseudomonas azotocolligans"
Anderson 1955, 132, in the genus Sphingomonas as Sphingomonas trueperi sp. nov. Int J Syst Bacteriol 47, 577-583.

Kawahara, K., Mizuta, I., Katabami, W., Koizumi, M. \& Wakayama, S. (1994). Isolation of Sphingomonas strains from ears of rice and other plants of family Gramineae. Biosci Biotechnol Biochem 58, 600-601.

Kim, S.-B., Yoon, J.-H., Kim, H., Lee, S. T., Park, Y.-H. \& Goodfellow, M. (1995). A phylogenetic analysis of the genus Saccharomonospora conducted with 16S rRNA gene sequences. Int J Syst Bacteriol 45, 351-356.

Lee, J.-S., Jung, M.-C., Kim, W.-S. \& 10 other authors. (1996). Identification of lactic acid bacteria from kimchi by cellular FAMEs analysis. Kor J Appl Microbiol Biotechnol 24, 234-241.

Manaia, C. M., Nunes, O. C., Morais, P. V. \& Da Costa, M. S. (1990). Heterotrophic plate counts and the isolation of bacteria from mineral waters on selective and enrichment media. J Appl Bacteriol 69, 871-876.

Marmur, J. (1961). A procedure for the isolation of DNA from microorganisms. J Mol Biol 3, 208-218.

Nohynek, L. J., Suhonen, E. L., Nurmiaho-Lassila, E.-L., Hantula, J. \& Salkinoja-Salonen, M. (1995). Description of four pentachlorophenol-degrading bacterial strains as Sphingomonas chlorophenolica sp. nov. Syst Appl Microbiol 18, 527-538.

Nohynek, L. J., Nurmiaho-Lassila, E.-L., Suhonen, E. L., Busse, H.-J., Mohammadi, M., Hantula, J., Rainey, F. \& SalkinojaSalonen, M. S. (1996). Description of chlorophenol-degrading Pseudomonas sp. strains $\mathrm{KF}^{\mathrm{T}}$, KF3, and $\mathrm{NKF1}$ as a new species of the genus Sphingomonas, Sphingomonas subarctica sp. nov. Int J Syst Bacteriol 46, 1042-1055.

Quevedo-Sarmiento, J., Ramos-Cormenzana, A. \& GonzalezLopez, J. (1986). Isolation and characterization of aerobic heterotrophic bacteria from natural spring waters in the Lanjaron area (Spain). J Appl Bacteriol 61, 365-372.

Saitou, N. \& Nei, M. (1987). The neighbor-joining method: a new method for reconstructing phylogenetic trees. Mol Biol Evol 4, 406-425.

Shin, Y. K., Lee, J.-S., Chun, C. O., Kim, H.-J. \& Park, Y.-H. (1996). Isoprenoid quinone profiles of the Leclercia adecarboxylata KCTC 1036 ${ }^{\mathrm{T}}$. J Microbiol Biotechnol 6, 68-69.

Skerman, V. B. D. (1967). A Guide to the Identification of the Genera of Bacteria, 2nd edn. Baltimore: Williams \& Wilkins.

Stackebrandt, E. \& Liesack, W. (1993). Nucleic acids and classification. In Handbook of New Bacterial Systematics, pp. 152-189. Edited by M. Goodfellow \& A. G. O’Donnell. London: Academic Press.

Takeuchi, M., Kawai, F., Shimada, Y. \& Yokota, A. (1993). Taxonomic study of polyethylene glycol-utilizing bacteria: emended description of the genus Sphingomonas and new descriptions of Sphingomonas macrogoltabidus sp. nov., Sphingomonas sanguis sp. nov. and Sphingomonas terrae sp. nov. Syst Appl Microbiol 16, 227-238.

Takeuchi, M., Sakane, T., Yanagi, M., Yamasato, K., Hamana, K. \& Yokota, A. (1995). Taxonomic study of bacteria isolated from plants: proposal of Sphingomonas rosa sp. nov., Sphingomonas pruni sp. nov., Sphingomonas asaccharolytica sp. nov., and Sphingomonas mali sp. nov. Int J Syst Bacteriol 45, 334-341.

Tamaoka, J. \& Komagata, K. (1984). Determination of DNA base composition by reversed phase high-performance liquid chromatography. FEMS Microbiol Lett 25, 125-128.

Taylor, D. N., McDermott, K. T., Little, J. R., Wells, J. G. \& Blaser, M. J. (1983). Campylobacter enteritis from untreated water in the Rocky Mountains. Ann Intern Med 99, 38-40. 
Thompson, J. D., Higgins, D. G. \& Gibson, T. J. (1994). CLUSTAL $\mathrm{W}$ : improving the sensitivity of progressive multiple sequence alignment through sequence weighting, position-specific gap penalties and weight matrix choice. Nucleic Acids Res 22, 4673-4680.

Wilkes, H., Wittich, R.-M., Timmis, K. N., Fortnagel, P. \& Francke, W. (1996). Degradation of chlorinated dibenzofurans and dibenzo-p-dioxins by Sphingomonas sp. strain RW1. Appl Environ Microbiol 62, 367-371.

Yabuuchi, E., Tanimura, E., Ohyama, A., Yano, I. \& Yamamoto, A. (1979). Flavobacterium devorans ATCC 10829: a strain of Pseudomonas paucimobilis. J Gen Appl Microbiol 25, 95-107.

Yabuuchi, E., Yano, I., Oyaizu, H., Hashimoto, Y., Ezaki, T. \& Yamamoto, H. (1990). Proposals of Sphingomonas paucimobilis gen. nov. and comb. nov., Sphingomonas parapaucimobilis sp. nov., Sphingomonas yanoikuyae sp. nov., Sphingomonas adhaesiva sp. nov., Sphingomonas capsulata comb. nov., and two genospecies of the genus Sphingomonas. Microbiol Immunol 34, 99-119.

Yabuuchi, E., Kosako, Y., Naka, T., Suzuki, S. \& Yano, I. (1999). Proposal of Sphingomonas suberifaciens (van Bruggen,
Jochimsen and Brown 1990) comb. nov., Sphingomonas natatoria (Sly 1985) comb. nov., Sphingomonas ursincola (Yurkov et al. 1997) comb. nov., and emendation of the genus Sphingomonas. Microbiol Immunol 43, 339-349.

Yang, P., Vauterin, L., Vancanneyt, M., Swings, J. \& Kersters, K. (1993). Application of fatty acid methyl esters for the taxonomic analysis of the genus Xanthomonas. Syst Appl Microbiol 16, 47-71.

Yano, I., Tomiyasu, I. \& Yabuuchi, E. (1982). Long chain base composition of strains of three species of Sphingobacterium gen. nov. FEMS Microbiol Lett 15, 303-307.

Yoon, J.-H., Lee, S. T., Kim, S.-B., Kim, W. Y., Goodfellow, M. \& Park, Y.-H. (1997). Restriction fragment length polymorphism analysis of PCR-amplified 16S ribosomal DNA for rapid identification of Saccharomonospora strains. Int J Syst Bacteriol 47, 111-114.

Yoon, J.-H., Lee, S. T. \& Park, Y.-H. (1998). Inter- and intraspecific phylogenetic analysis of the genus Nocardioides and related taxa based on 16S rDNA sequences. Int $J$ Syst Bacteriol 48, 187-194. 